\section{Prevalence and characteristics of Brazilians aged 50 and over that received a doctor's diagnosis of COVID-19: the ELSI-COVID-19 initiative}

\author{
Prevalência e características de brasileiros com \\ 50 anos ou mais que receberam um diagnóstico \\ médico de COVID-19: iniciativa ELSI-COVID-19
}

\author{
Prevalencia y características de brasileños con \\ 50 años o más que recibieron el diagnóstico de \\ COVID-19 de un doctor: la iniciativa \\ ELSI-COVID-19
}

James Macinko 1 Brayan V. Seixas 1 Natalia Oliveira Woolley 1 Fabiola Bof de Andrade 2 Maria Fernanda Lima-Costa 2,3

doi: 10.1590/0102-311X00190320

\begin{abstract}
The severe acute respiratory syndrome coronavirus 2 (SARS-CoV-2) has caused over half a million deaths worldwide. Brazil has been particularly impacted, registering more than 1.3 million infections and 57,000 deaths by late June 2020. Aggregate numbers of cases are essential in modeling the epidemic and planning responses; however, more detailed analysis of risk factors associated with SARS-CoV-2 infection are needed. Our study provides an initial examination of characteristics associated with receiving a doctor's diagnosis of COVID-19 among a nationally representative sample of Brazilians aged 50 and over. Data are derived from the second wave of the Brazilian Longitudinal Study of Aging (ELSI-Brazil) and a telephone follow-up survey to ELSI-Brazil participants, known as the ELSI-COVID-19 initiative. The telephone survey was conducted between 26 May and 8 June 2020. Results show that about $2.4 \%(n=70)$ of the sample reported being told by a doctor they had COVID-19, however, only about half of these individuals $(n=37)$ reported receiving a diagnostic confirmation from viral testing (RT-PCR). Demographic factors (aged 50-60 years), socioeconomic factors (lower household income), health-related factors (obesity, three or more chronic conditions), and geography (living in the Northern region of the country) were positively associated with reporting a COVID-19 diagnosis. Despite the descriptive and preliminary nature of these findings, results reported here suggest the need for more targeted approaches to enhance personal protection and provide greater viral testing options, especially for older, sicker and more vulnerable adults in Brazil.
\end{abstract}

COVID-19; Health Services for the Aged; Aged; Health of the Elderly
COMUNICAÇÃO BREVE

BRIEF COMMUNICATION 


\section{Introduction}

The severe acute respiratory syndrome coronavirus 2 (SARS-CoV-2), responsible for the COVID-19 pandemic, has spread quickly and caused at least 10 million infections and nearly half a million deaths worldwide. As of June 2020, Brazil was the world's second most impacted country with over 1.4 million infections and nearly 60,000 deaths (Coronavírus Brasil. Painel coronavírus. https://covid.saude. gov.br/, accessed on 21/Jun/2020).

Although the epidemic has taken different forms in different national settings 1 , several factors appear to be associated with COVID-19 complications and death, namely older age, being male, having one or more chronic diseases (e.g. diabetes, heart failure, chronic obstructive pulmonary disease) and having a high body mass index (BMI) 2 . Some sociodemographic factors have also been linked to increased risk, such as being from a racial/ethnic minority group and having a low income 3,4.

Viral testing is necessary to detect current SARS-CoV-2 infection 5 . However, testing is limited in Brazil, where the average number of daily tests has been 14 per 100,000 people, compared to 58 people in the United States and 61 in Chile ${ }^{6}$. In the absence of widespread testing, a doctor's diagnosis may be able to support monitoring and treatment, infection prevention and mitigation.

Our study explores factors associated with reporting a doctor's diagnosis of COVID-19 among a nationally-representative sample of Brazilian adults aged 50 and over.

\section{Methods}

The Brazilian Longitudinal Study of Aging (ELSI-Brazil) is aimed at elucidating social and biological aspects of aging. Baseline assessments took place in 2015-2016, and included a total of 9,412 people across 70 municipalities in all five major Brazilian geographic regions. A detailed description of the study aims and methods can be found elsewhere 7.

Data collection for the second wave of ELSI-Brazil started in August 2019 but was suspended in March 2020 due to the COVID-19 outbreak. To assess the impact of the epidemic on ELSI participants, a 5-minute telephone interview was developed to be applied to all wave 2 participants and addressed personal protective behaviors, social and economic difficulties, use of health services, and COVID-19 symptoms and medical diagnoses.

Trained interviewers conducted the telephone assessments between May 26th and June 8th using an electronic template for data entry. The final response rate for the telephone interview was $67 \%$. Of the non-responses, about 5\% declined to participate, about one-third did not answer any of the five subsequent calls, and about $58 \%$ had a missing or inaccurate phone number. The survey weighting procedure was adjusted for these non-responders. The results presented here are therefore nationally representative of the Brazilian population aged 50 and over. Lima-Costa et al. 8 describe in detail the telephone survey protocol.

\section{Measures}

The main outcome is whether participants reported being told by a doctor that he/she had COVID-19. Explanatory variables include demographics (gender, age, relationship status, race/skin color), socioeconomic status (household income-divided into quintiles and educational attainment), geography (region and rural residence), chronic disease status (previously diagnosed with asthma, arthritis, cancer, depression, diabetes, heart disease, hypertension, kidney disease, Parkinson's, or Alzheimer's disease), self-rated health, body mass index (from measures of participant height and weight and categorized into normal weight, overweight and obese), smoking status, and receipt of a flu shot in the past 12 months as an indicator of propensity to seek preventive care. 


\section{Statistical analysis}

We present descriptive statistics as weighted proportions and statistical significance is obtained by a Wald or F test due to the complex survey data 9. Logistic regression is used to assess the association of multiple factors with receipt of a COVID-19 diagnosis. Logistic regression models were built in a step-wise fashion, retaining only variables that were statistically significant and/or improved model fit, as measured by Bayesian information criterion (BIC) and Akaike's information criterion (AIC) statistics. All analyses were controlled for the survey complex design and include final sample weights.

The ELSI-Brazil study and the ELSI-COVID-19 initiative were approved by the Committee on Research Ethics of the René Rachou Institute of the Oswaldo Cruz Foundation, Minas Gerais State (CAAE: 34649814.3.0000.5091 and 33492820.3.0000.5091, respectively).

\section{Results}

In total, 2.4\% (95\% confidence interval - 95\%CI: 0.05-10.05) of the sample (70 individuals) reported being told by a doctor that he/she had COVID-19. Out of these, only approximately half of the cases (37 individuals) stated the diagnosis was confirmed by a viral test (data not shown). Table 1 shows that the mean age among those who reported a COVID-19 diagnosis was significantly lower than the mean age among those not diagnosed. The proportion of individuals with self-designated brown skin color was higher among those with a positive COVID-19 diagnosis. Almost 65\% (95\%CI: 25.3-91.0) of all positive diagnoses for COVID-19 occurred among people in the second lowest income quintile and a similar proportion had three or more chronic conditions. For those without a COVID-19 diagnosis, only about $14 \%$ (95\%CI: 11.3-17.1) had three or more chronic conditions. When examining chronic conditions individually, the only ones associated with a COVID-19 diagnosis were diabetes, heart disease and cancer (data not shown). Obesity was nearly twice as prevalent among those that reported a positive diagnosis for COVID-19. Over 62\% (95\%CI: 12.9-94.9) of the individuals that reported being told by a doctor of a positive COVID-19 diagnosis lived in the North Region, whereas only $6.4 \%$ of the entire sample resided there.

\section{Table 1}

Characteristics of Brazilians aged 50 and over with a doctor's diagnosis of COVID-19. The ELSI-COVID-19 initiative.

\begin{tabular}{|c|c|c|c|c|}
\hline Variables & $\begin{array}{l}\text { No COVID-19 diagnosis } \\
\qquad \begin{array}{c}(n=6,071) \\
\text { OR }(95 \% \mathrm{Cl})\end{array}\end{array}$ & $\begin{array}{l}\text { COVID-19 diagnosis } \\
(n=70) \\
\text { OR }(95 \% \mathrm{Cl})\end{array}$ & $\begin{array}{c}\text { Total } \\
(\mathrm{N}=6,141) \\
\text { OR }(95 \% \mathrm{Cl})\end{array}$ & p-value * \\
\hline Age (mean) & $63.42(62.42-64.42)$ & $56.95(52.71-61.20)$ & $63.26(62.2-64.3)$ & 0.0389 \\
\hline Female & $53.9(50.99-56.79)$ & 77.69 (40.65-94.65) & $54.47(51.29-57.61)$ & 0.1696 \\
\hline \multicolumn{5}{|l|}{ Skin color } \\
\hline White & $53.09(45.70-60.35)$ & $15.65(3.51-48.59)$ & $52.20(44.30-59.99)$ & 0.0029 \\
\hline Brown & $36.08(30.18-42.44)$ & 78.68 (47.01-93.88) & $37.10(30.31-44.43)$ & \\
\hline Black & $9.83(7.36,13.02)$ & $5.51(2.22-13.05)$ & $9.73(7.28-12.89)$ & \\
\hline Other & $0.99(0.48-2.05)$ & $0.17(0.01-2.97)$ & $0.97(0.47-2.02)$ & \\
\hline \multicolumn{5}{|c|}{ Marital situation } \\
\hline Partnered & $60.13(56.18-63.96)$ & $36.59(7.87-79.59)$ & $59.57(55.17-63.83)$ & 0.3047 \\
\hline \multicolumn{5}{|c|}{ Schooling (years) } \\
\hline$<5$ & $18.00(15.32-21.02)$ & $6.28(2.80-13.49)$ & $17.72(15.00-20.81)$ & 0.1135 \\
\hline $5-8$ & $27.26(24.32-30.41)$ & $11.73(1.99-46.47)$ & $26.89(24.30-29.65)$ & \\
\hline 9 or more & $54.74(50.11-59.29)$ & 81.98 (47.78-95.77) & $55.39(50.93-59.76)$ & \\
\hline
\end{tabular}

(continues) 
Table 1 (continued)

\begin{tabular}{|c|c|c|c|c|}
\hline \multirow[t]{2}{*}{ Variables } & $\begin{array}{l}\text { No COVID-19 diagnosis } \\
\qquad(n=6,071)\end{array}$ & $\begin{array}{l}\text { COVID-19 diagnosis } \\
\qquad(n=70)\end{array}$ & $\begin{array}{c}\text { Total } \\
(N=6,141)\end{array}$ & \multirow[t]{2}{*}{ p-value * } \\
\hline & OR $(95 \% \mathrm{Cl})$ & OR $(95 \% \mathrm{Cl})$ & OR $(95 \% \mathrm{Cl})$ & \\
\hline \multicolumn{5}{|l|}{ Household income (quintiles) } \\
\hline Q1 (poorest) & $20.37(17.11-24.07)$ & $5.03(0.93-22.90)$ & $20.00(16.77-23.68)$ & 0.0077 \\
\hline Q2 & $20.3(16.88-24.21)$ & $64.96(25.32-91.02)$ & $21.37(17.16-26.28)$ & \\
\hline Q3 & $18.65(16.00-21.64)$ & $14.35(4.48-37.43)$ & $18.55(16.04-21.35)$ & \\
\hline Q4 & $20.32(17.12-23.95)$ & $10.20(3.01-29.41)$ & $20.08(16.84-23.77)$ & \\
\hline Q5 (richest) & $20.36(16.39-25.00)$ & $5.46(0.86-27.70)$ & $20.00(16.03-24.67)$ & \\
\hline Current smoker & $11.48(9.98-13.17)$ & $4.70(0.57-29.65)$ & $11.32(9.76,13.09)$ & 0.3586 \\
\hline Received Flu shot & $66.03(61.93-69.91)$ & 35.84 (7.24-79.99) & $65.31(60.78-69.59)$ & 0.1903 \\
\hline \multicolumn{5}{|l|}{ Chronic conditions } \\
\hline 0 & $35.03(31.35-38.89)$ & $12.78(3.09-40.23)$ & $34.50(30.87-38.32)$ & 0.0005 \\
\hline 1 & $31.11(29.02-33.27)$ & $17.05(5.41-42.49)$ & $30.77(28.51-33.13)$ & \\
\hline 2 & $19.91(18.00-21.97)$ & $4.85(0.83-23.71)$ & $19.55(17.58-21.69)$ & \\
\hline 3 or more & $13.96(11.32-17.09)$ & $65.32(25.42-91.23)$ & $15.18(11.96-19.08)$ & \\
\hline Poor self-rated health & $12.29(10.25-14.66)$ & $7.63(1.33-33.57)$ & $12.18(10.11-14.59)$ & 0.5611 \\
\hline Any $A D L$ limitation & $11.09(8.79-13.88)$ & $3.67(0.65-18.11)$ & $10.91(8.60-13.74)$ & 0.1600 \\
\hline \multicolumn{5}{|l|}{ BMI } \\
\hline Normal weight ** & $28.42(25.77-31.23)$ & $3.98(0.59-22.48)$ & $27.8(25.20-30.55)$ & 0.069 \\
\hline Overweight & $39.99(37.01-43.05)$ & $19.17(4.90-52.22)$ & $39.46(35.90-43.14)$ & \\
\hline Obese & $29.97(27.70-32.35)$ & 76.85 (38.77-94.56) & $31.17(27.52-35.07)$ & \\
\hline \multicolumn{5}{|l|}{ Geographic regions } \\
\hline North & $4.99(1.85-12.77)$ & 62.59 (12.91-94.97) & $6.36(1.79-20.26)$ & $<0.001$ \\
\hline Northeast & $26.96(17.42-39.24)$ & $23.10(3.74-69.88)$ & $26.87(17.33-39.18)$ & \\
\hline Southeast & $41.23(28.64-55.08)$ & $13.72(2.18-53.11)$ & $40.58(27.93-54.61)$ & \\
\hline South & $16.38(7.73-31.42)$ & $0.42(0.03-5.20)$ & $16.00(7.53-30.84)$ & \\
\hline Central & $10.43(4.79-21.25)$ & $0.17(0.01-2.95)$ & $10.19(4.66-20.84)$ & \\
\hline Rural residence (versus urban) & $12.7(9.26-17.18)$ & $8.56(1.25-40.94)$ & $12.60(9.12-17.16)$ & 0.6483 \\
\hline
\end{tabular}

95\%Cl: 95\% confidence interval; ADL: activities of daily living; BMI: body mass index; OR: odds ratio.

Note: numbers are weighted percentages and their $95 \% \mathrm{Cl}$.

* From F-tests adjusted for complex sample design and individual weights;

** Includes underweight (BMI < 18.5) because sample size for this group is small $(n=163)$.

Table 2 presents adjusted odd ratios (OR) and 95\%CI obtained from logistic regression. Each additional year of age (over 50) is associated with $6 \%$ (OR $=0.94$; 95\%CI: 0.91-0.98) lower odds of having a COVID-19 diagnosis, all else equal. The adjusted odds of a positive COVID-19 diagnosis is ten times higher for those with three or more chronic conditions when compared with those with none. Likewise, obese individuals have on average almost eight times higher odds of COVID-19 diagnosis than those with normal weight. Those in the second lowest income group had six times the odds among those in the lowest income quintile, all else equal. Living in any region other than the North Region is associated with at least $83 \%(\mathrm{OR}=0.17$; $95 \% \mathrm{CI}$ : $0.05-0.59)$ lower odds of a positive COVID-19 diagnosis.

\section{Discussion}

This is the first study conducted with a representative sample of Brazilian people aged 50 and over to shed light upon important characteristics of those who have been diagnosed with COVID-19. Nearly $2.4 \%$ of the weighted sample reported being told by a doctor that he/she had COVID- 19 . This is com- 
Table 2

Logistic regression of characteristics of Brazilians aged 50 and over with a doctor's diagnosis of COVID-19 ( $n=70)$. The ELSI-COVID-19 initiative.

\begin{tabular}{lc}
\hline Variables & Adjusted OR (95\%Cl) \\
\hline Female & $1.46(0.56-3.76)$ \\
Age (continuous) & $0.94 *(0.91-0.98)$ \\
Chronic conditions & \\
$\quad 1$ (versus 0) & $2.2(0.64-7.52)$ \\
2 & $1.03(0.26-4.07)$ \\
3 or more & $10.31 *(2.15-49.45)$ \\
Overweight (versus normal weight) & $3.31(0.75-14.67)$ \\
Obese (versus normal weight) & 7.74 * $(2.19-27.38)$ \\
Income (quintiles) & \\
Q2 (versus 1, poorest) & $6.07 * *(1.53-24.09)$ \\
Q3 & $4.17(0.79-21.95)$ \\
Q4 & $2.74(0.63-11.86)$ \\
Q5 (richest) & $1.88(0.33-10.78)$ \\
Geographic regions & \\
Northeast (versus North) & $0.17 *(0.05-0.59)$ \\
Southeast & $0.05 * * *(0.01-0.18)$ \\
South & $0.01 * * *(0.00-0.06)$ \\
Central & $0.00 * * *(0.00-0.05)$ \\
N & 5,486 \\
\hline
\end{tabular}

95\% Cl: 95\% confidence interval; OR: odds ratio.

Note: OR and $95 \% \mathrm{Cl}$ : estimated from logistic regression models.

All estimates control for the study design and include individual weights.

* $\mathrm{p}<0.01$;

** $\mathrm{p}<0.05$;

$\star \star \star p<0.001$.

pared to the estimated current infection rate of about $0.6 \%$ in the entire population, based on current numbers (https://covid.saude.gov.br/, accessed on 21/Jun/2020). Despite participants being in some of the most vulnerable groups, diagnostic confirmation from viral testing was limited to just $50 \%$ of the participants that reported receiving a doctor's diagnosis.

Based on our final regression model, several factors were found to be associated with receiving a positive COVID-19 diagnosis that bear further discussion. First, regional differences are consistent with the pattern of the epidemic observed during the study period, in which the North Region had COVID-19 rates (about 97/10,000), which is more than three times that of the national average $(27 / 10,000) 10$

Second, ability to adhere to preventive behaviors may be an important driver for some of these results. People in lower income groups may be more likely to live in overcrowded housing, may need to continue working even during a lockdown, and may lack access to clean water and sanitation. Nevertheless, the highest likelihood of COVID-19 diagnosis was found among those in the second lowest (when compared with the lowest) income group. This result may be due to the small sample size and the non-uniform spread of the virus. However, it may indicate income-related differences in awareness of COVID-19 signs and symptoms or access to health services if verified in future waves of the study.

Third, higher rates of COVID-19 diagnosis among those experiencing obesity or multimorbidity were expected, given current knowledge about risk factors for more severe forms of the disease and the fact that these individuals may be more likely to routinely visit a doctor for ongoing care. 
Finally, middle-aged participants in our study were more likely than older survey respondents to report a diagnosis. Although older age is a risk factor for COVID-19 complications and death 11, it is not necessarily an indicator of risk of infection, which is driven by contact with people carrying the virus. This explanation is also consistent with the observation that older (aged 60 and over) study participants were considerably less likely to report leaving their houses in the past 30 days than were those aged 50-59 over the May/June 2020 period (data not shown).

Our study presents some limitations. First, the sample size is small and we cannot confidently rule out that some of our odd ratios are overly inflated. Unfortunately, alternative statistical approaches such as penalized maximum likelihood estimation cannot incorporate the complex sample design. Second, recall bias is always possible, although this is arguably a minor threat to internal validity given the current attention to the coronavirus pandemic. Third, it is not possible to control for potential biases in physician screening and diagnosis and there is no known literature on the accuracy of doctor diagnoses of COVID-19 to this date due to the novelty of the topic. Finally, it is possible that some portion of telephone survey non-responses were due to individuals that were too sick to answer the phone, in which case the results presented here may be underestimated.

Despite these limitations, our study shows important characteristics of older adults that have received a positive diagnosis for COVID-19. In the context of a continuously evolving epidemic scenario in Brazil, the ELSI-COVID initiative provides an important tool for identifying individual and contextual characteristics of those that might be more impacted by COVID-19. These characteristics may help to focus viral testing efforts, inform public information campaigns and alert health services to characteristics of the population most affected by the pandemic. Further studies remain necessary to determine the persistence of the associations found and their underlying mechanisms.

\section{Contributors}

J. Macinko conducted the study design, data analysis, contributed to the manuscript writing and supervised the research. B. V. Seixas and N. O. Woolley contributed to the manuscript writing and revision. F. B. Andrade participated in the data collection and study design. M. F. Lima-Costa directed the data collection and study design. All authors reviewed and approved the final version for publication of the article.

\section{Additional informations}

ORCID: James Macinko (0000-0001-8055-5441); Brayan V. Seixas (0000-0002-3863-0572); Natalia Oliveira Woolley (0000-0002-3780-7006); Fabiola Bof de Andrade (0000-0002-3467-3989); Maria Fernanda Lima-Costa (0000-0002-3474-2980).

\section{Acknowledgments}

The baseline and second wave of the ELSI-Brasil aging cohort study was funded by the Brazilian Ministry of Health: Department of Science and Technology of the Department of Science and Technology and Strategic Inputs - DECIT/SCTI) (grant n. 404965/2012-1 and 28/2017) and Health Coordination for the Elderly of the Health Care Secretariat - COSAPI/DAPES/SAS (TED: 20836, 22566, 23700 and 77/2019). The ELSI-COVID-19 initiative is funded by DECIT/SCTI and by the Brazilian National Research Council (CNPq: grant n. 403473/2020-9). 


\section{References}

1. Schellekens P, Sourrouille D. COVID-19 mortality in rich and poor countries: a tale of two pandemics? World Bank Policy Research Working Paper n. 9260 2020; 1 jun. https:// papers.ssrn.com/sol3/papers.cfm?abstract_ $\mathrm{id}=3614141$.

2. Tamara A, Tahapary DL. Obesity as a predictor for a poor prognosis of COVID-19: a systematic review. diabetes \& metabolic syndrome. Clinical Research \& Reviews 2020; 14:655-59.

3. Yancy CW. COVID-19 and African Americans. JAMA 2020; 323:1891-2.

4. Centers for Disease Control and Prevention. Coronavirus disease 2019 (COVID-19). Health equity considerations and racial and ethnic minority groups. https://www.cdc.gov/ coronavirus/2019-ncov/need-extra-precau tions/racial-ethnic-minorities.html (accessed on $29 /$ jun/2020).

5. Centers for Disease Control and Prevention. Coronavirus disease 2019 (COVID-19). Test for current infection. https://www.cdc.gov/ coronavirus/2019-ncov/testing/diagnostictesting.html (accessed on 29/Jun/2020).

6. Johns Hopkins Coronavirus Resource Center. How does testing in the U.S. compare to other countries? https://coronavirus.jhu.edu/ testing/international-comparison (accessed on 29/Jun/2020).

7. Lima-Costa MF, Bof de Andrade F, Souza Jr. PRB, Neri AL, Duarte YAO, Castro-Costa E, et al. The Brazilian Longitudinal Study of Aging (ELSI-Brazil): objectives and design. Am J Epidemiol 2018; 187:1345-53.
8. Lima-Costa MF, Macinko J, Andrade FB, Souza Jr. PRB, Vasconcellos MTL, Oliveira CM. ELSI-COVID-19 initiative: methodology of the telephone survey on coronavirus in the Brazilian Longitudinal Study of Aging. Cad Saúde Pública 2020; 36 Suppl 3:e00183120.

9. Heeringa SG, West BT, Berglund PA. Applied survey data analysis. London: Chapman and Hall; 2010.

10. Cota W. Monitoring the number of COVID-19 cases and deaths in Brazil at municipal and federative unit level. SciELO Preprints 2020; 7 may. https://preprints.scielo.org/index.php/ scielo/preprint/view/362.

11. Garg S, Kim L, Whitaker M, O’Halloran A, Cummings C, Holstein R, et al. Hospitalization rates and characteristics of patients hospitalized with laboratory-confirmed coronavirus disease 2019 - COVID-NET, 14 States, March 1-30, 2020. MMWR Morb Mortal Wkly Rep 2020; 69:458-64. 


\section{Resumo}

A síndrome respiratória aguda grave coronavírus 2 (SARS-CoV-2) já causou mais de meio milhão de mortes em todo o mundo. O Brasil foi particularmente afetado, registrando mais de 1,3 milhão de infecções e 57 mil mortes no final de junho de 2020. Embora o número agregado de casos seja essencial na modelagem da epidemia e no planejamento de respostas sanitárias, uma análise mais detalhada dos fatores de risco associados à infecção também é necessária. Este estudo fornece uma visão inicial das características associadas ao recebimento do diagnóstico médico de COVID-19 em uma amostra nacionalmente representativa de brasileiros com 50 anos ou mais. Os dados são derivados da segunda onda do Estudo Longitudinal da Saúde dos Idosos Brasileiros (ELSI-Brasil) e de uma pesquisa de acompanhamento por telefone aos participantes do ELSI-Brasil, conhecida como iniciativa ELSI-COVID-19. A pesquisa por telefone foi administrada entre 26 de maio e 8 de junho de 2020. Os resultados mostram que cerca de $2,4 \%(n=70)$ dos participantes relataram ter sido informados por seu médico que tinha COVID-19, mesmo que apenas a metade desses indivíduos $(n=37)$ relatou ter recebido uma confirmação diagnosticada por teste viral. Fatores demográficos (idade entre 50-60 anos), fatores socioeconômicos (renda familiar mais baixa), fatores relacionados à saúde (obesidade, três ou mais condições crônicas) e geografia (viver na região norte do pais) foram associados positivamente com um diagnóstico de COVID-19. Apesar da natureza descritiva e preliminar aqui descrita, os resultados sugerem a necessidade de abordagens mais direcionadas para aumentar a proteção pessoal e fornecer mais opções de teste viral, especialmente para adultos mais velhos, mais doentes e mais vulneráveis no Brasil.

COVID-19; Serviços de Saúde para Idosos; Idoso; Saúde do Idoso

\section{Resumen}

El sindrome respiratorio agudo grave coronavirus 2 (SARS-CoV-2) ha causado más de medio millón de muertes en todo el mundo. Brasil se ha visto particularmente afectado, registrando más de 1,3 millones de infecciones y 57.000 muertes hasta finales de junio 2020. Mientras las cifras globales del número de casos son esenciales en el modelado de la epidemia y en la planificación de respuestas, existe la necesidad de un análisis más detallado del riesgo de factores asociados con la infección de SARS-CoV-2. Este estudio proporciona un examen inicial de características asociadas, al recibir el diagnóstico de COVID-19 por parte del médico, entre una muestra representativa a nivel nacional de brasileños con 50 años o más. Los datos procedian de la segunda serie del Estudio Brasileño Longitudinal del Envejecimiento (ELSI-Brasil) y una encuesta telefónica de seguimiento a los participantes en el ELSI-Brasil, conocida como la iniciativa ELSI-COVID-19. La encuesta telefónica fue administrada del 26 mayo al 8 junio 2020. Los resultados muestran que sobre un 2,4\% $(n=$ 70) de la muestra informó que su médico les comunicó que tenían COVID-19, pese a que solo aproximadamente la mitad de estos individuos $(n=37)$ informaron haber recibido un diagnóstico de confirmación con un test viral (RT-PCR). Los factores demográficos (edad entre 50-60 años), factores socioeconómicos (ingresos por hogar más bajos), factores relacionados con la salud (obesidad, tres o más enfermedades crónicas), y geografía (residentes en las regiones del norte del pais) estuvieron todos positivamente asociados con un diagnóstico de COVID-19. A pesar de la naturaleza descriptiva y preliminar de estos hallazgos, los resultados obtenidos aqui sugieren la necesidad de enfoques más específicos para mejorar la protección personal y proporcionar mejores opciones de test virales, especialmente para los adultos mayores más vulnerables y más enfermos en Brasil.

COVID-19; Servicios de Salud para Ancianos; Ancianos; Salud del Anciano
Submitted on $01 / \mathrm{Jul} / 2020$

Final version resubmitted on 12/Aug/2020

Approved on 17/Aug/2020 